\title{
The Munitions Worker as Trickster in Wartime Japan
}

\section{BENJAMIN UCHIYAMA}

Following Japan's invasion of China in 1937, Japanese bureaucratic and intellectual elites constructed a volatile image of the munitions worker as trickster. Within this discursive realm, the worker became an object of hope, fear, and rage for the guardians of an idealized home front struggling to bolster war production while still adhering to wartime goals of national austerity. In the cultural fantasies and nightmares of the Japanese home front, the munitions worker fluctuated between the valorized "industrial warrior" laboring for the nation and a violent delinquent ready to wreak havoc on society.

Keywords: Japan, mobilization, total war, workers, World War II

$\mathrm{D}$ URING the Asia-PaCifiC War (1937-45), the mischievous munitions worker was one of the most powerful tricksters on the Japanese home front. As metaphor, cultural construct, and the personification of society's deepest hopes and fears, the trickster intermittently upsets the official order. His deception and mockery of the status quo are disruptive but not fatally so, for he never completely overthrows the system. What the trickster does do, however, is expose the hollow arbitrariness of official ideologies, thereby cracking open new imaginings of a more revitalized world (Hyde 1998, 6-9; Hynes and Doty 1997, 34-44). In wartime Japan, the munitions worker became a trickster within the discursive anxieties of Japanese police, intellectuals, and bureaucrats in reaction to the unexpected tumult of labor mobilization. The onset of war led to the mass conscription of adult men into the armed services and a severe labor shortage on the home front. Labor scarcity provided workers in real life and the worker in the popular imagination opportunities to loyally serve the state in munitions factories but also to revolt against state imposition of socioeconomic controls. This ambiguity led the munitions worker to be simultaneously valorized and despised in official and popular discourse.

An examination of the munitions worker as trickster has profound implications for thinking about modern Japanese history. Wartime Japan is usually characterized as a moment when national mobilization, labor controls, and rationing rapidly curbed consumer spending to the point of extinction (Francks 2009; Havens 1978; Rice 1990; Tansman 2009). This perspective meshes well with the often-told story of the triumph of a hegemonic "culture of thrift" that prioritized economic frugality and the subordination of personal desire for national goals. According to this narrative, state-directed wartime savings campaigns and policing of factory youth contributed to the establishment of a modern, rational, and disciplined middle-class way of life that went on to define

Benjamin Uchiyama (buchiyam@usc.edu) is Assistant Professor in the Department of History at the University of Southern California. 
postwar Japanese society (Ambaras 2006; Garon 1997, 2000). Drawing on these valuable insights, the munitions worker serves as a heuristic device for exploring an alternative side to wartime modernity that celebrated not austerity but avarice, not obedience but disobedience, not discipline but disorder. War mobilization did empower the state to reconfigure Japan's prewar class society into a rational and function-based "total war system" (Yamanouchi 1998, 3-4). But mobilization also sowed the seeds for new social conflict by granting a privileged group of workers the resources to engage in the modern-day practice of "binge consumption."1 The misbehavior of munitions workers enraged conservative guardians of an austere and disciplined vision of the Japanese home front. And yet, the critical role the munitions worker played in sustaining Japan's war machine, along with the abetting of factory owners and the military services, shielded him from the most onerous state labor controls. Thus, the social impact of the war years for Japanese subjects was quite varied. For some it meant repression, but for others it meant an opportunity to escape limitations. The state's struggle to respond to that reality reveals that wartime mobilization could both intensify official tools of social control but also undermine state authority.

Previous studies of Japanese munitions workers have fixated on their state exploitation following the 1939 enactment of labor conscription (Havens 1978, 91-97; Katō Yūji 1970; Rice 1990). While acknowledging this coercive dimension, other scholars have highlighted the modern, rationalizing characteristics of the wartime labor system. Andrew Gordon (1985, 257-326) demonstrates how workers in wartime evaded labor and wage controls through job-switching, slowdowns, and sabotage. The ineffectiveness of labor controls forced factory owners and bureaucrats to implement innovative workplace reforms beneficial to workers, which laid the foundations for Japan's famous postwar employment system. Sasaki Kei $(2005,2011)$ also finds that the wartime state combined coercion with "positive" campaigns promoting worker welfare benefits and "labor culture" to enhance worker productivity.

Thinking about the munitions worker as trickster builds on this scholarship by illuminating a cultural dimension to the dynamic relationship between labor and war mobilization. The unanticipated social turmoil of mobilizing for total war and the subsequent inability of the official order to permanently discipline real-life munitions workers contributed to a multifaceted construction of the munitions worker in the popular imagination. These fantasies of munitions workers circulating in the Japanese media after 1937 would go on to shape and reshape wartime labor mobilization. While Japanese civilians were harangued by official calls to sacrifice and economize for the war, they learned from the media about the munitions worker's glittering life on the home front. In the 1939 Japanese comedy film Enoken no ganbari senjutsu (Enoken's tough tactics), middleclass passengers aboard a first-class train car watch in stunned silence as rowdy factory youths break into boisterous song over a newly won 30 percent pay raise: "It's our

\footnotetext{
${ }^{1}$ According to the theory of binge consumption, marginalized groups cut off from traditional social institutions and subsisting on irregular income tend to binge their earnings on hedonistic pleasureseeking. This is not a throwback to premodern practices but a phenomenon rooted in modern industrial capitalism. That is, as Richard Wilk $(2006,125)$ writes, "the binge is always present in capitalist consumerism, for even if it is suppressed or concealed, it is always the logical complement, the 'evil twin' lurking in the background behind the ideology of thrift...."
} 
world now - and what a fantastic time it is! Bankers and office workers don't even come close.... Let’s drink sake and sing! Money is no object! Let's be outrageous and go crazy!" (Furukawa 2003, 118-19).

The munitions worker claimed the mantle of the patriotic "industrial warrior" while scorning state-promoted values of thrift and self-discipline. As middle-class salarymen struggled to get by in a new era of rationing, sacrifice, and shortages, the worker outrageously gorged on the consumerist pleasures of the home front. "Wartime" was his world now-and what a strange, fantastical time it was.

\section{Early Wartime Mobilization and Its Consequences}

The munitions worker emerged out of a society mobilizing for total war. When the China War erupted in the summer and fall of 1937, the government called up hundreds of thousands of adult men for military service. By December 1937, nearly 600,000 men were conscripted into the army. By the end of 1938, as the China War slowed into a quagmire, the military had mobilized 1.33 million soldiers in China (Tasaki and Arakawa 1988, 185-86). To cope with a severe labor shortage in the munitions sector, the government unleashed a torrent of labor control legislation. In October 1937, the Home Ministry created a system of employment agencies that would allocate workers based upon labor requests from munitions plants (Yamazaki 2011, 354-58). In January 1938, the Welfare Ministry was founded at the Army's behest to be the primary agency spearheading labor mobilization (Gordon 1985, 262; Rice 1990, 31). Subsequent legislation, such as the 1938 National Mobilization Law and the Revised Employment Exchange Law, empowered the Welfare Ministry to, among other things, impose extensive controls and restrictions on labor, wages, and private enterprises in order to maximize the nation's economic productivity in time of war, as well as coordinate all employment agencies toward the new state mission of "industrial labor placement" (Dai Nippon shokugyō shidō kyōkai 1939, 34-35).

State efforts to draw young men into the munitions industry saw an immediate impact. From 1937 to 1941, the number of male factory workers grew from 2.1 million to 3.6 million (Kyōchōkai 1942 supplement, 22-23). The accelerating growth in munitions workers was particularly acute in Army-run arsenals. In 1937, there were 88,124 workers in all Army arsenals. This figure jumped to 137,981 in 1938, 152,318 in $1939,174,464$ in 1940, and 215,790 in 1941. Even this expansion was not enough for munitions factories to keep pace with the military demand for weapons and supplies. In 1940, Army arsenals nationwide were still operating at only 60 percent capacity (Yamazaki 2011, 359-60). To cope with the manpower shortage, the government issued the National Labor Conscription Ordinance in July 1939 to begin conscripting workers. However, it was not until 1941, when the possibility of war with the United States loomed, that the government invoked the full force of labor conscription to mobilize workers en masse. Until then, labor conscripts constituted a relatively small proportion of the industrial workforce with only 850 conscripts in 1939 and 53,000 conscripts in 1940 called up (Awaya 1977, 182-84).

Press coverage of the booming munitions industry helped publicize the opportunities awaiting young workers. These stories laid the first building blocks for constructing 
the image of the munitions worker as trickster by highlighting not only the economic benefits workers could receive but how unrighteous, unnatural, and excessive their wages were. In the fall of 1937, one investigative reporter discovered that a leather factory that normally employed 200 workers was hiring an additional 500 temps to keep up with the military demand for boots and belts. At this particular site, workers were earning over 100 yen per month with two hours' overtime, dwarfing the then-average monthly factory salary of 35 yen (Hashimoto [1937] 1975). By the summer of 1938, newspapers were reporting that Mitsubishi Heavy Industries gave out 250 percent bonuses while Hitachi Factory, Nakajima Aircraft, and Tokyo Gas announced bonuses of up to 150 percent to attract and keep workers (Kitagawa 1988, 235). More reliable figures suggest a less sensational but still significant growth in factory pay. According to official military statistics, the average monthly wage of an army arsenal worker grew from 60.64 yen in 1937 to 90.52 yen by 1941 (Yamazaki 2011, 367).

Journalist Sugiyama Heisuke, writing for Gendai (Modern times) magazine in August 1938, called on the government to "balance out this unevenness." Businesses in the so-called "peace industries" (heiwa sangyō) such as silk and textiles, he wrote, were suffering under strict wartime controls that severed access to the China market and critical raw materials. By contrast, the "wartime industries" (senji sangyō) were flourishing. Sugiyama concluded, "There are some who are extremely lucky and others who are extremely unlucky because of the war. This is not a good thing" (Sugiyama 1938, 87-88).

In August 1938, bureaucrats from no less than seven ministries (Home Affairs, Finance, Commerce and Industry, Army, Navy, Justice, and Welfare) held a conference to discuss the growing problems of the "imbalanced economy" (hakō keizai). The conference attendees claimed that munitions workers were "chuckling over their bonuses and raises" while those in the "peace industry" suffered layoffs and unemployment. Echoing Sugiyama's remarks, they reserved the bulk of their public statement to admonish the munitions industry: "It is only in the military munitions sector where many are wastefully and extravagantly spending due to their pay raises. This is a most serious matter." The bureaucrats urged workers to "refrain from wasteful spending" and "follow the national policy line in wartime" by putting their excess wages into savings accounts (Tokyo Asahi shinbun 1938a). Shortly thereafter, the Welfare Ministry announced a plan to establish "home front daily life reform groups" (jūgo seikatsu sasshin han) in all factories to encourage workers to save their earnings instead of "ignoring the Finance Ministry's savings campaign" by engaging in "wasteful spending” (Tokyo Asahi shinbun 1938b).

A juvenile delinquency expert similarly decried the growing economic dislocations brought on by mobilization, which, he said, created a "lopsided economic boom" (henzai keiki). With fathers away fighting on the frontlines and mothers forced to make ends meet by working outside the home, the writer argued, factory youths were irresponsibly earning high wages without adult supervision: "Many of them earn about three yen a day or fifty to sixty yen per month. This rapid rise in income allows for easy spending binges. Not a few of these youths wear extremely gaudy clothes and shoes. Many frequent cafés and coffee houses." And when the money is gone, "many descend into crime" (Maeda 1938, 56). A university professor, writing for the intellectual journal Kaizō (Reconstruction), likewise observed that juvenile delinquency seemed to be most pronounced around munitions factories. He claimed that because workers were earning inappropriately large sums of money, they were "recklessly indulging 
themselves in pleasure" (Nagasawa 1939, 268). In Gunma Prefecture, the Purity League (junketsu dōmei), a nationwide group of Japanese Protestant social activists, became alarmed at growing licentious activities around local munitions factories. Starting in 1938, league members made repeated visits to the factories to teach workers to follow a more austere and morally self-disciplined life (Onozawa 2006).

In May 1939, the writer Koiwai Kiyoshi bitterly complained about munitions workers in downtown Tokyo, where they flaunted their newfound wealth in a time of national austerity. Recalling that, before the war, social divisions were between the city and countryside, he argued that "now the divide is between the munitions industry and small businesses." In his view, the munitions boom brought about two undesirable social trends among factory workers — spending sprees and juvenile delinquency. "Frequently," he claimed, "it is a factory worker ordering an expensive item at the department store.... $[\mathrm{T}]$ hese are nouveau-riche workers who defy national policy by engaging in reckless spending and foolish carousing.... When one thinks about our young men risking their lives today fighting on the continent, one becomes quite disturbed at this lack of personal propriety and spiritual mobilization" (Koiwai 1939, 100). Koiwai's complaints reflected the growing axiomatic belief on the home front that the war had created an unfair division between those who were in the munitions industry and those who were not, and that young munitions workers were inappropriately earning excessive wages to splurge on frivolous activities during a time of crisis.

After 1939, the government began taking stronger actions to rein in worker spending and job-switching. An April 1939 Welfare Ministry decree ordered workers to secure government approval before switching to a higher-paying factory job. However, this decree proved ineffective when factory owners simply gave workers forged consent forms. A special Welfare Ministry task force later created to investigate and punish workers lacking the required papers was similarly stymied by uncooperative factory owners refusing to provide information to the inspectors (Tokyo Asahi shinbun 1939a).

The government more forcefully addressed the economic unevenness of the wartime boom with the September 1939 Stop Ordinance (stoppu rei). The ordinance froze wage levels for all workers to curb escalating wartime inflation and resolve the growing pay imbalance between the munitions industries and non-munitions sectors (Gordon 1985, 286). Economic bureaucrats who drafted the decree blamed "undeserved salary raises" as the root cause of wartime inflation. To demonstrate the need for the Stop Ordinance, one newspaper claimed that the highest-paid worker at a munitions plant in Kamata was earning over 1,000 yen per month-more than the salary of the Japanese prime minister. “The Health and Welfare Minister," the newspaper claimed, "was reportedly stunned by this fact" (Tokyo Asahi shinbun 1939b).

The Stop Ordinance was followed by the September 1940 Revised Wage Control Ordinance, which established maximum wages according to gender, age, industry, and location, along with a total aggregate wage quota that employers were barred from exceeding. However, these state efforts to control the real wages of munitions workers had mixed results, for the military demand for munitions continued unabated, workers freely job-switched for higher pay, and factory owners resorted to extra-legal means to lure in and keep workers (Gordon 1985, 286). In 1942, the Home Ministry Economic Police belatedly discovered that factories routinely handed out secret "black market wages" (yami chingin) to workers in order to get around wage controls. According to a 
police report from that year, "in the Tokyo region, one hears that "up to 99 percent is black market wages." The police blamed the rampant use of "black market wages" on a "shortage of workers, lack of controls over sub-contracting fees, and unequal treatment in official wages." Efforts to stamp out this practice were hampered, police complained, by collusion between factory owners and military officials prioritizing production over wage controls (Akazawa, Kitagawa, and Yui 1985, 112).

By February 1940, a cartoon appeared in Kingu (King) magazine lampooning the breathtaking status reversal between factory worker and middle-class salaryman in the new wartime economy. Titled "Company man and factory worker" (Shain to shokkō), the cartoon consisted of two panels. In the first panel, labeled "Before," a company man is dressed in top hat, suit, and dress shoes and is carrying a briefcase. The gentleman nonchalantly tosses aside a cigarette to the ground. A worker dressed in a worker's cap, overalls, and sandals bends over to pick up the cigarette, while muttering, "My goodness! What a waste!" The next panel, labeled "Now," shows a quite different scene. This time it is the worker wearing shiny black shoes and casually tossing aside a cigarette while the poor company man, now in sandals, stoops down to pick it up. The once-proud company man grumbles, "Huh, the boom must be great!" (Ohata 1940).

\section{The Contested Identities of The Munitions Worker}

By January 1940, a reader's letter to the Yomiuri shinbun observed that "the word 'worker' (shokkō) has an offensive connotation" (Yomiuri shinbun 1940a). As the public debates about binge-spending munitions workers unfolded alongside announcements of one ineffective wage control ordinance after another, a rough image of the munitions worker took shape on the home front. Technically, workers in munitions factories came in many categories, including students, unmarried women, and unemployed male adults. However, the munitions worker provoking public anxieties crystalized into a generally agreed-upon image. He was usually between seventeen and twenty, right around the cusp of conscription age, when many munitions workers were taken into military service. ${ }^{2}$ The typical worker as delinquent was an elementary school graduate-educated but not middle class and often from a rural background. The munitions worker was often associated with carrying swords, machine tools, or other makeshift weapons stolen from the worksite. According to a labor specialist writing in 1940, police arrested a "gang" (furyōdan) of seventeen- to eighteen-year-old workers at a Tokyo munitions factory. "Of late," the exasperated labor expert sighed, "almost all delinquents now work in the factories, bringing home income to help their parents, while making extra money by

\footnotetext{
${ }^{2}$ According to the "Delinquent youth arrest statistics" (Furyō shōnen kenkyo tōkei), which analyzed 22,534 juvenile delinquents arrested from August to September 1942, 9 percent $(2,136)$ were seventeen years old, 14 percent $(3,228)$ were eighteen years old, 17 percent $(3,930)$ were nineteen years old, and 20 percent $(4,534)$ were twenty years old. The numbers decline for older age groups: 17 percent $(3,817)$ for twenty-one-year-olds, 6 percent $(1,138)$ for twenty-two-year-olds, 4 percent (983) for twenty-three-year-olds, 3 percent (663) for twenty-four-year-olds, and 4 percent $(1,056)$ for twenty-five-year-olds. Over 50 percent of these youths were classified as factory workers. Clearly, military conscription decimated the ranks of factory youths once they reached the draft age of twenty (Kyōchōkai 1944, 98-99).
} 
selling tools taken from factories." Arrest or dismissal of every thieving munitions worker was not a viable option for factory owners due to labor scarcity. At another large factory, according to a police report, the supervisor opted not to fire a worker for theft. "In today's spirit of the age," the report lamented, "one cannot easily do such a thing. The reason is that this man was quite useful and skillful." This "useful and skillful" worker, together with six accomplices, had smuggled out 8,000 yen worth of machine tools from the factory to sell on the black market (Himuro 1941, 13-15).

Hair greasy from pomade was another characteristic linked in the popular imagination to the mischievous munitions worker and, by extension, a distinctive style of wartime delinquency. One juvenile court judge in 1940 warned parents that greasy hair along with outlandish clothing was a sure sign of juvenile delinquency (Tokyo Asahi shinbun 1940b). In 1941, an indignant magazine writer denounced as unpatriotic the sight of "monstrous" young men loitering on the streets of the Ginza with "flashy suits" and their "ridiculous use of pomade," which left "a lingering oily smell on their head" (Kikuta 1941). Despite the association with illicit behavior, pomade sales increased during the war. According to a 1941 Japanese cosmetics industry report, "among all cosmetic products, none has brought about a tremendous jump in demand like pomade. Currently, one sees pomade everywhere, from the urban areas to the corners of remote mountain regions" (Shokugyō kyōkai 1942, 278-81). The commercial success of pomade in spite of wartime scarcities was partly due to the cosmetics industry's adoption of synthetic ingredients to substitute for scarce and rationed oil (Tōkyō komamono keshōhin shōhōsha 1943, 99).

The pomade boom was also due to the expansion of the customer base from the relatively small circle of middle-class office workers to the more numerous factory youths with the money and desire to purchase such a product. The July 1940 advertisement for Yanagiya pomade was typical of early wartime pomade marketing to the white-collar salaryman: "the essential item for the home front gentleman!" Traditional pomade advertisements usually featured an urban professional in a Western suit (see, e.g., Yomiuri shinbun 1937, 1938, 1939, 1940f). Beginning in December 1941, images of salarymen were replaced by text assuming a tone catering toward a younger and more working-class audience: "All Citizens Work! (Kokumin kairō da!) Youths of Japan defend the home front with both body and mind neat and tidy (kiriri toshite)" (Yomiuri shinbun 1941). The next batch of Yanagiya advertisements strengthened the link between workers and pomade. From May to September 1942, advertisements featured the image of a smiling young man with neatly combed hair wearing a collared factory uniform. The text above the picture invoked the common wartime slogan directed at workers: "For warriors on the frontlines of increased production (zōsan) — stand tall and firm with a neat and tightened mind and body" (Yomiuri shinbun 1942a, 1942b). From October 1942 to March 1943, pomade advertisements identified even more explicitly the worker as their ideal consumer. The image on display was of a young man with slickly combed hair in a worker's uniform next to the shadow profile of a man wearing a worker's cap. The caption below read, "Make the heart and head bright and cheerful! Let's enthusiastically fight to the bitter end" (Yomiuri shinbun 1942d, 1943a).

Though frequently depicted by the mass media in a worker's cap and collared factory uniform, the munitions worker was also imagined to be in disguise. Beginning in 1940, 
several media accounts claimed that munitions workers masqueraded as students. ${ }^{3}$ According to the writer Hayashi Tatsuo, groups of workers would pose as "fake students" (nise gakusei) in the commuter trains between Tokyo and Yokohama. They appeared to be elite college or higher school students wearing the traditional Prussian-style dark navy blue uniforms with brass buttons and lapel badges. However, while regular students talked about sports or music, Hayashi observed that the phony students would exchange vulgar stories about women. What is more, in spite of the recent state crackdown on luxuries, the workers sported big, shiny rings that no ordinary student could afford or should wear (Hayashi 1940).

Periodic press accounts of police raids in cafés fed into the image of the worker as "fake student." "A wickedness created by the thriving industries," screamed the sensational headlines of the Tokyo Asahi shinbun on April 9, 1940. Police announced the mass arrest of over 2,000 youths loitering late at night in Tokyo streets, some armed with razors and swords stolen from the worksite. "Factory workers as fake students were the most conspicuous," one officer noted. Most of the youths were released from custody after writing an official apology and receiving a stern warning (Tokyo Asahi shinbun 1940a). In highly distilled form, both Hayashi and the newspaper highlighted the most offensive elements of the munitions worker as trickster-conspicuous consumer, larcenous delinquent, and master of disguise and deception.

The phenomenon of "fake students" invoked public memories of an earlier association between masquerade and juvenile delinquency. During the 1920s, Tokyo street gangs would kidnap and force students to join their group. As argued by David Ambaras, "Lower-class gangs could thus simultaneously mock and embrace the symbols of the dominant culture." By the 1930s, some urban youths masqueraded as students to cavort with café waitresses in Tokyo. This led to routine police crackdowns on students spending time in dance halls, movie theaters, or cafés, based on the theory that such sites of pleasure would lead to wasteful spending and eventually a life of crime (Ambaras 2006, 144-45, 160-61).

Worker practices blurring class boundaries and celebrating mass consumption acquired a particularly politicized and subversive edge during the Asia-Pacific War in the eyes of middle-class social reformers and bureaucrats trying to police leisure activities. At the same time, many of these same critics pushed for a reinvention of workers into more disciplined and productive imperial subjects.

This anxiety about the growing affluence of munitions workers and their clothing was amplified in the April 1940 issue of the Yomiuri shinbun, which ran a series of articles about juvenile misbehavior, the second installment of which was called "The desire for student uniforms: When taking off the blue work overalls slackens the heart." The article told the story of a seventeen-year-old factory worker, Tsuruda Nobukichi, who was led astray down the dark path of masquerade by a co-worker, eighteen-year-old Sakamoto Ichirō, who recently started wearing a "dark navy blue student uniform." Sakamoto later meets up with Nobukichi at a café, where they encounter three more factory youths, also dressed up in student uniforms like Sakamoto. The fake students glare at Nobukichi, still in his factory work clothes, and sneer, "well look who's arrived! It's the master

${ }^{3}$ Kitagawa Kenzō (1988, 239-40) was the first to note in passing the curious phenomenon of "fake students," which he attributed to the growing affluence of munitions workers. 
mechanic." At the café, Sakamoto tells Nobukichi that he is skipping work in order to moonlight as a subcontractor at a higher-paying factory, which pays 150 yen a month. With the extra cash, he bought a student uniform to wear at the movie theater. "Hey, what about you?" Sakamoto suddenly inquires of Nobukichi. "If you come to my apartment, I've got a student uniform. I'll lend it to you-just this one night. Let's go." The detail about the subcontracting system echoes later Economic Police reports about "black market wages" being especially prevalent among factory subcontractors. The story also reinforced popular fears about older workers leading naïve factory youths astray and invoked longtime public apprehensions of the café as a denizen of moral vice (Silverberg 2006, 73-107). Nobukichi ends up spending 35 yen for his own student uniform so that he can live "a double life-factory work clothes in the day, student uniform at night." He eventually repents his actions and discards the uniform. Sakamoto and his fellow uniform-wearing "delinquent factory youths" are later arrested by police as "hooligans" (yotamono). Despite the abrupt, didactic conclusion, the fictionalized newspaper anecdote illustrated the ambiguous place of the munitions worker in the popular imagination. He could be both a good-hearted, if susceptible and naïve, young man and a dangerous, delinquent pleasure-seeker lurking in the shadows (Yomiuri shinbun 1940d).

The same month, the Yomiuri shinbun invited readers to share their own opinions about "fake students." One anonymous reader complained in a letter, "it is said that there are many fake students in delinquent raids; mostly factory youths. They wear school caps with school uniforms. But what else should they wear? It's not as if they can secretly wear a suit" (Yomiuri shinbun 1940b). A few days later, another reader wrote in to comment about workers masquerading as students. "Currently, there is nothing else that is adequate [for workers to wear] aside from the student uniform and student cap. We really have to work hard to avoid the so-called American style (merikengata) of replacing the uniform button with a specially made button showing the company's insignia and, similarly, the company's insignia on an extremely short-brimmed hat." Another concerned citizen opined, "I have no particular objection over the student uniform, but it would be best if they wore clothing which has absolutely no gold buttons." A reader helpfully suggested that workers adopt a recent Army fashion of a turned-down collar (suten karā) decorated "not with a gold button but with a plain black button. And what about wearing a hunting cap instead of overdoing it with a student cap?" (Yomiuri shinbun 1940c). The reader responses in the Yomiuri shinbun suggest that some members of the public recognized that current workers' uniforms were somehow legitimately unsatisfying to workers, but a proper replacement was yet to be found. In this small way, the Yomiuri shinbun provided a platform for readers to anonymously participate in the public debate about reconfiguring the identity and look of the factory worker that rendered him ambiguously deviant and sympathetic.

The growing public discussion on munitions worker attire reflected a broader movement about clothing reform in total war. Toward the end of 1940 and into 1941, rationing and austerity to conserve materials assumed a renewed importance on the home front. On July 7, 1940, the government announced the Regulations Restricting the Production and Sale of Luxury Items to lower inflation and redirect precious resources away from consumer spending and toward war production and savings bonds (Shōkōshō bukka kyoku 1940). Growing public intolerance of flagrant consumption by anyone, male or 
female, was further cemented in November 1940 when the government introduced the austere "national uniform" (kokumin fuku) for all men to wear in place of the Western suit. The national uniform and the luxuries ban were state attempts to push all Japanese subjects to subordinate private desire for the war, conserve scarce material resources, and smooth over social tensions arising from economic differences under the munitions boom (Naitō 2007, 150-51; Wakakuwa 2006, 196-97).

In this context, attempts by young munitions workers using their "undeserved" earnings to purchase elite status with new attire provoked much public criticism. In a commentary on "public morals" in the summer of 1941, the writer Hagiwara Sakutarō described his firsthand encounter this time not with "fake students" but with "sham gentlemen" (gisō shinshi)—workers dressed in suits like urban professionals. When one goes to bars, Hagiwara noted, there are usually "shady-looking" salarymen with neatly pressed suits. But all is not what it seems upon closer inspection: "The look of a salaryman is that of an intellectual who finished school, mixed with the style of an obsequious snob... But the men sitting next to me were not of this type at all. Their look was not a bit like that of the intellectual" (Hagiwara 1941, 84). The clothing of these impostors troubled Hagiwara, for they were "purposefully mimicking gentlemen and students." He explained that since the war started, workers had a quite different goal in masquerade than during the 1920s: "They do not think simply about 'flirting with women.' Rather, they want to buy respect as full-fledged members of society (shakaijin)." Watching "every move and action," workers "did not want to be seen as rising upstarts of low birth but as splendid gentlemen with education and status." In order to fit in with the expensive leisure sites they were now able to patronize, the writer noted, munitions workers began wearing Western suits or uniforms from elite colleges and middle schools. "In this way," Hagiwara sniffed, “an 'instant gentleman' and 'instant student' is born” (Hagiwara 1941, 84-85). He expressed irritation that workers were using their newfound wealth to buy their way into the middle class without proper middle-class upbringing or education.

On the other hand, what perhaps perturbed Hagiwara and others even more was that munitions workers were not really aspiring to be middle-class salarymen at all. By knowingly assuming the persona of salaryman in the presence of real salarymen who saw through the façade, the worker demonstrated how fluid, fragile, and inauthentic such class identities ultimately were. The worker was not passing but performing as middle class. By not aspiring toward but mimicking salaryman identity, knowing very well he is not fooling anyone, the worker exposed the hollowness of middle-class visions of modern life centered on rationality, frugality, and discipline. If a figure as outrageous, irrational, and violent as a munitions worker could so casually mimic a student or "gentleman," the foundations of middle-class identities of actual salarymen were now called into question. What also made masquerade so offensive to the intelligentsia was the worker as trickster introducing new modes of behavior that reconfigured hegemonic assumptions about modern society. His disingenuous mimicry of a pseudo-intellectual suggested that workers, not intellectuals, were beginning to articulate new social mores. A warning to parents from a Tokyo middle school official expanded on this middle-class anxiety toward workers. The educator blamed young workers for leading middle school students into a life of delinquency. "Before," he wrote, "middle school gang leaders were so-called fallen ex-students. But recently among delinquent gangs 
I have studied, a great many workers have become the leaders" (Yomiuri shinbun 1940e). In other words, what made wartime juvenile delinquency so disturbing in the popular press was not simply that they grew in scale but that they were being committed by the wrong kind of people-young workers, not middle-class students.

\section{Defining Worker Identity in Late Wartime}

The state unwittingly played along with this cultural trend-setting "performance" by trying to capture and isolate the positive dimensions of the worker as trickster from his more undesirable traits. The failure of the 1939 Stop Ordinance convinced labor specialists in the Welfare Ministry to supplement punitive wage control measures with welfare benefits in order to induce more disciplined worker behavior. This policy shift not only further blurred the ambiguous place of the munitions worker on the home front, but also paved the way for his official consecration as noble "industrial warrior" (sangyō senshi) worthy of the same public acclaim as that given to soldiers. The November 1940 New Labor Order announcement, issued by the Cabinet Planning Board, declared that labor was now a sacred and honorable duty performed by all subjects of the empire. Under the clarion call of the New Labor Order, state officials and labor scientists pushed factories to improve treatment of workers for the public interest and move away from practices motivated only by private profit (Sasaki 2011, 57; Takaoka 2001, 39-42).

Many labor experts joined the staff of the Greater Japan Patriotic Labor Association (Dai Nippon Sangyō Hōkokukai, commonly referred to as Sanpō) which planned popular musical programs and comedy shows for boosting workers' morale and productivity. However, despite a favorable reception from workers, after December 1941, the Sanpō's cultural activities were taken over by the new Imperial Rule Assistance Association (IRAA) Culture Department. The IRAA activists promoted a quite different vision of "labor culture" (kinrō bunka), which demanded that workers follow "wholesome" cultural practices based on an organic "worker's culture" and not on crass mainstream mass culture. Accordingly, in 1942 and 1943, under IRAA influence, Sanpō culture units stopped performing popular songs and comic routines for workers and instead shifted toward performances of pedantic patriotic plays and "national people's songs" (kokumin uta). Through such "wholesome" leisure practices, the IRAA activists believed, workers would not only become more productive in the worksite but also adopt a more rational and disciplined daily life. These forms of entertainment became quite unpopular among workers, who did not flinch from voicing their disapproval. Beginning in August 1943, Sanpō and IRAA culture units slowly reverted back to popular storytelling and comedic show performances (Takaoka 2001, 37-71).

While bureaucrats and social reformers wrestled with the question of what exactly "labor culture" should look like in order to simultaneously please and motivate workers, public anxieties about the munitions worker diminished as the government shifted toward almost exclusive reliance on labor conscription following the expansion of the war into the Pacific theater in 1941. Thereafter, the demographics of munitions workers drastically diverged from the image of the Japanese teenaged male delinquent. To keep factories at capacity, the government pulled the remaining non-munitions adult male labor force into factory work in 1941, then students and women in 1943, and finally forcibly conscripted 
1.5 million Korean and 38,000 Chinese colonial subjects in 1944 and 1945 (Awaya 1977, 182-84). By the end of the war in 1945, over six million people across gender, age, and ethnic lines were mobilized to work in factories and mines (Sasaki 2005, 26).

Nevertheless, signs of worker trickery characteristic of early wartime Japan continued to appear in the Pacific War era. In October 1942, a magazine writer still noted that factory youths, not college students, were the most frequent patrons of urban amusement centers: "The cafés are thriving with young industrial warriors seeking out relaxation as they uneasily hold up their cigarettes." The journalist recounted that Tokyo police launched yet another crackdown on factory workers loitering in cafés and movie theaters, arresting 9,900 people and confiscating over 800 weapons. He observed that these youths were "making too much money" and "growing increasingly wild living in dull dormitories" (Yoshimura [1942] 1975, 88-90).

Worker masquerade was cited and even embraced by at least one observer in 1942 . Economic journalist Nishitani Yahei welcomed the mixing of sartorial styles between students and workers, believing that this would enable each group to adopt the unique traits of the other and thereby strengthen the nation. "It has become common to not know whether he is a middle school student or a so-called industrial warrior," he wrote. “... [I]n many ways, this is a good thing” (Nishitani 1942, 392-95). For some Japanese, new cultural practices among workers provoked fury and jealousy; for others, such behavior could inspire discussions that made the home front seem more human, more real, and simply more alive.

By 1942, the government created no less than three medals specifically to honor the patriotic labor of "industrial warriors" (Yomiuri shinbun 1942c). The next year, factories boldly advertised even more perks awaiting workers at the worksite. The Aichi Machine Tools Arsenal paid for a two-page photo montage advertisement touting reasonable hours of operation (7:30 a.m. to 4:30 p.m.), major holidays off (plus every Tuesday), and opportunities for work-sponsored leisure activities such as a "boys' factory worker wind orchestra." The Asia Leatherworks Factory listed impressive workplace amenities in its advertisement-baseball club, sumō club, table tennis club, fishing club, and hiking club. Starting salary was to be 75 sen (presumably a daily wage) with two raises per year. This was on top of a monthly "perfect attendance" allowance, bonuses, a family allowance, "incentive pay" (shōreikin), a tuition subsidy for night school, and a free dormitory equipped with an "entertainment room," a "reading room," and an on-site health clinic (Itō 1943, n.p.).

At the same time, throughout 1943, newspapers repeatedly warned the public about malicious munitions workers prowling the dark city streets disguised as "fake detectives" (nise keiji) to rob people (Tokyo Asahi shinbun 1943; Yomiuri shinbun 1943b, 1943d). In October 1944, the Tokyo Police Agency announced the mass arrest of over 10,000 factory youths engaging in theft and carousing (Tokyo Asahi shinbun 1944).

In June 1943, under the leadership of Finance Minister Kaya Okinori, the government launched a renewed campaign to bolster national savings among civilians for the war effort (Aramata 1996, 82-97). ${ }^{4}$ However, the one group that eluded his grasp was

${ }^{4}$ The winning entry for the Finance Ministry's savings slogan contest was "From Bursting Sweat, Gushing Savings" (fuki deru ase kara waki deru chochiku). 
munitions workers. Right when his savings campaign got underway, the government quietly abolished wage caps, thereby restoring the ability of factories to openly offer pay raises to workers. Government leaders decided that such wage controls were impeding the ultimate goal of maximizing weapons production (Gordon 1985, 287). Meanwhile workers' salaries continued to jump. Starting with the index level of 100 in 1937, wages grew to 136.4 in 1942, 145.3 in 1943, and 159.2 in 1944. Wartime inflation tempered the true value of these wage hikes. From 1939 to 1944, inflation soared by over 200 percent. But factories compensated for inflation with illegal overtime pay, incentive pay, allowances, and other unofficial, extra remuneration to retain skilled workers (Ōhara shakai mondai kenkyūjo 1964, 64-65). This may explain Kaya’s later frustration with workers in the "thriving industries" (inshin sangyō) who ignored his grand savings campaign by engaging in "wasteful spending." He accused them of harboring "old individualism" for thinking that wages were "their own money and theirs to spend" (Garon 2000, 58).

The dire war situation and the insatiable military demand for munitions continued to override austerity campaigns when it came to workers' wages. In October 1943, the Diet passed the sweeping Munitions Company Law to break through the bottlenecks found in inefficient weapons production. The law authorized the military services to bypass the Welfare Ministry and industrial cartel middlemen and issue contracts directly to munitions firms; relaxed preexisting controls over prices, wages, and labor; and guaranteed a minimum level of profit for firms. A Munitions Ministry, staffed by reform bureaucrats, was also created to centralize all munitions production under one agency (Mimura 2011, 174-81).

This legislation helped destroy whatever lingering wage controls remained in the munitions sector. The Munitions Company Law empowered a new group of elites to sweep in and defend workers from wage controls and moral opprobrium. Munitions Ministry bureaucrats repudiated the Welfare Ministry's practice of imposing a single undifferentiated punitive wage control policy across all companies. Kitano Shigeo, in a 1944 explanatory guide to the law, argued that such wage controls not tailored toward workers" needs created "hindrances" in hiring and production. What Japan needed, he wrote, was "a wage system that is compatible for all firms." Reversing years of official disapproval of spiraling workers' wages, the bureaucrat stated flatly, "We have to think about raising compensation appropriately as efficiency advances and production grows." Kitano brushed aside public complaints about the unfair economic benefits enjoyed only by the munitions sector: "the sacrifice and adverse effects in other sectors simply cannot be helped" (Kitano 1944, 127, 130). The final year of the war witnessed the death blow to rational wage and labor controls when the military and munitions factories began to brazenly hoard as much materials and foodstuffs as possible to poach workers from other worksites. At the same time, the Economic Police's ability to enforce labor controls withered away, with the number of officers in Osaka alone shrinking from 388 in 1941 to 296 in 1944 (Nishida 1994, 387-92).

As state economic controls collapsed, industrial production sputtered to a standstill, and all consumer pleasures seemed to vanish into thin air, the munitions worker continued to make whimsical cameos in the mass cultural artifacts of late wartime Japan. In May 1943, Chiyoda Camellia Pomade, signaling the triumph of the munitions worker over the salaryman as the preferred consumer for male cosmetics, placed but a single image in its newspaper advertisement: a factory chimney bellowing smoke (Yomiuri shinbun 1943c). 
The final wartime advertisement for pomade appeared in February 1944. The advertisement for Yanagiya pomade showed a smiling young man with neatly combed hair, his disembodied hand holding a comb, and his factory uniform collar. Below, the text read: "Always bright, like the sun. Let's go out to the worksite (shokuba). Simple, economical, superior quality" (Yomiuri shinbun 1944). The wording highlighted the ambiguity of the munitions worker as cultural construct - the embodiment of a productive and economical laborer but also a privileged consumer who shamelessly used rationed oil to make his hair shine, "like the sun."

The visceral association of the munitions worker with binge spending, questionable sartorial style, and delinquency was visualized in a 1944 collection of cartoons by, appropriately enough, workers aspiring to be cartoonists. One worker contributed an illustration of the "blind, old-fashioned worker ... [and] delinquent factory youth who cast aside the honor of industrial warriors" (see figure 1). The cartoon was of an unshaven worker chomping on a cigarette while wearing a backwards worker's cap. With one hand, the worker grasps the arm of a frightened coworker, coercing the latter to hand over a wad of cash. With the other hand, the worker grips a large sake or wine bottle. An oversized pen is removing the label of the noble "industrial warrior" from his lapel while a large hand awaits to paste a new label of the despised "worker" (shokkō). Jutting from the worker's coat pocket is a jumbled collection of items symbolizing his decadent lifestyle-pocket watch, wristwatch, cash, and receipt from the "café" (Katō Etsurō 1944, 23). It is true, as Sasaki Kei $(2011,60-61)$ argues, that the cartoon visualized a concerted effort by labor bureaucrats to castigate the model of the rough and "old-fashioned" prewar worker in favor of the moral and dedicated "industrial warrior" befitting wartime. However, the image also invoked new popular imaginings of the worker constructed in wartime itself. Here, the worker was the powerful beneficiary of the wartime economy, unjustly enriching himself from the peculiar economic configurations of total war to engage in disruptive behavior: a patron of the modern eroticized space of the café, a consumer of a leisure culture seemingly disconnected from war, a violent extortionist, and an irreverent prankster who sloppily wears his worker's cap backwards.

Another drawing reinforced the perception among advocates of the "industrial warrior" that they were fighting against a new and unpleasant phantasm of total war. In this piece, a determined-looking worker is decked out in overalls and cap-properly worn forward — and holding a hammer while surrounded by iconic pictures representing the "hands of temptation." The caption explains that the patriotic "industrial warrior" bravely resists the tantalizing pleasures of greed, lust, gluttony, and violence symbolized by the following images: a money bag next to piles of cash, a beautiful woman with permed hair holding a martini glass, a sake bottle and a fish delicacy, a clawed hand labeled with the word "unfair," a cigarette resting on an ashtray emitting a puff of smoke, and a handgun (Katō Etsurō 1944, 32). The cartoon neatly captured the hopes and fears ascribed to the munitions worker as trickster in the twilight of wartime Japan.

\section{Conclusion}

Total war unleashed sweeping socioeconomic transformations in Japanese societytwisting official ideologies into new cultural forms that complicated the state's ability to 


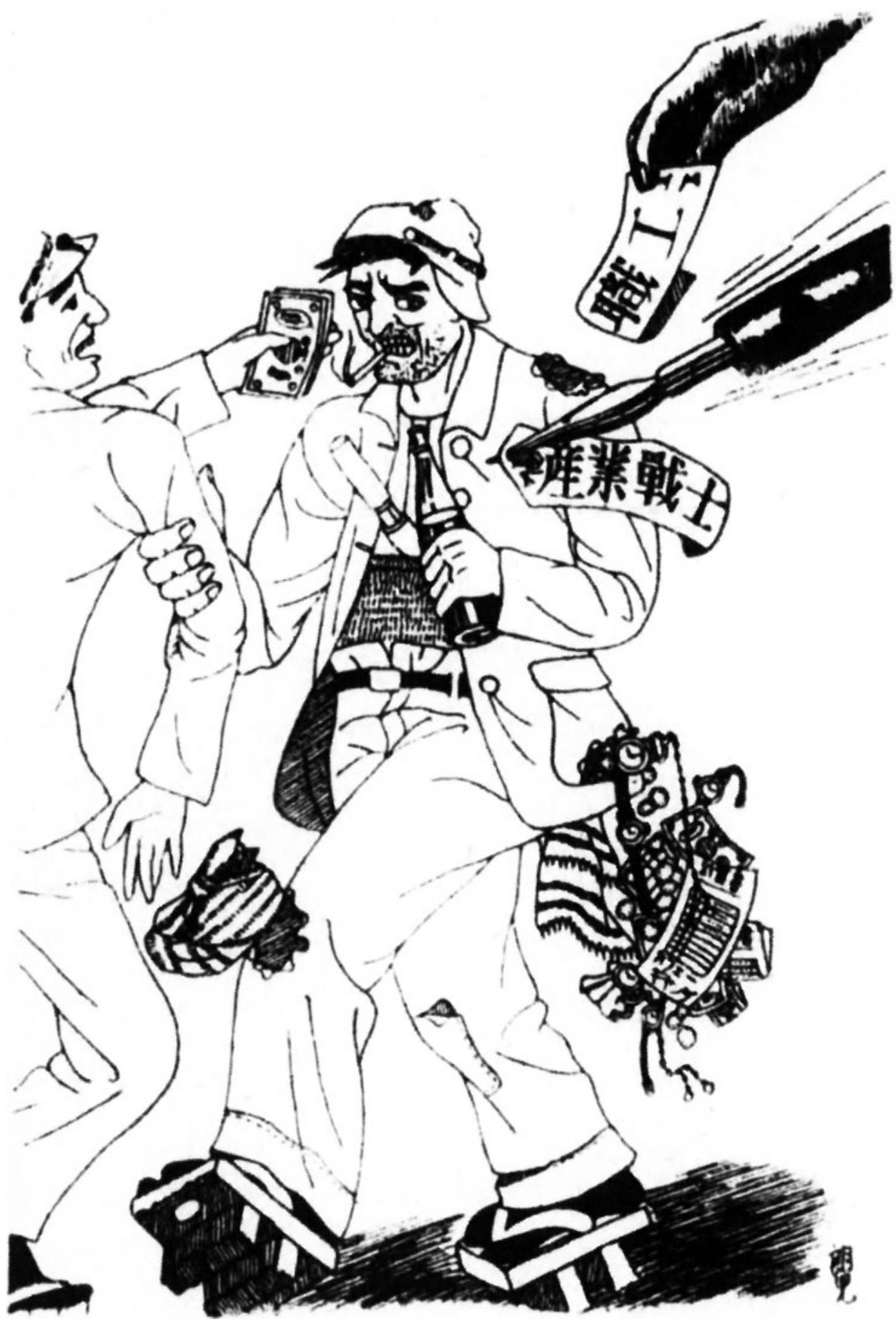

Figure 1. "Do not disgrace the name of the industrial warrior" (sangyō senshi no na wo yogosu nakare) (Katō Etsurō 1944, 23). 
reshape the home front into a single unified image. As the war expanded in the late 1930s and early 1940s, state agencies issued and reissued a bewildering web of contradictory labor regulations more honored in the breach than in the observance. Circulating alongside was an unstable official rhetoric that schizophrenically valorized and vilified workers. Within this cacophonous vortex stood the munitions worker as trickster-an elusive specter who defied easy categorization and control, a culturally imagined spawn of total war who shouldered Japan's entire industrial machinery and yet personified official anxieties that the "industrial warrior" would one day invert into a dangerous juvenile delinquent.

The munitions worker only imperfectly championed "resistance" against the total war system. Like all tricksters around the world, he operated not in direct opposition to the status quo but along the boundary between the realms of official and unofficial ideologies, ready to "move swiftly and impulsively back and forth across all orders with virtual impunity" (Hynes and Doty 1997, 34). This ambiguity made it difficult for state agencies to control his autonomy without jeopardizing the foundations of critical military production. The wartime state and the munitions worker were, in a way, "stuck" with each other. The state could crack down on the munitions worker to make him behave, but only to a limited extent, for the line between disciplining and sabotaging the worker was a fine one. Conversely, the worker's cultural aura resonated only within the fantasies and nightmares inspired by the state's ruthless attempts to mobilize society for war. Once the war ended and the total war system collapsed, the munitions worker as mischief-maker vanished from public consciousness. As Lewis Hyde explains, "if the ritual setting is missing, trickster is missing. If his companions-all the other spiritual forces within whose fixed domains he carries on his mischief - are no longer with us, then he is no longer with us" (Hyde 1998, 13). The trickster, in other words, needs the rituals of an authoritarian system both as a stage to perform on and as a foil against which to mock, destroy, and renew. Otherwise, he will dissipate into the ether as a directionless force of nature (BassilMorozow 2015, 87-88). This final characteristic elevates the munitions worker from mere cultural construct to trickster. He did not simply reflect social reality but rattled and rejuvenated it. The state laid out the rules for total war as system; the munitions worker promptly shattered those rules to reimagine total war as lived experience.

In all these ways, the munitions worker represented the messy cultural politics of "resistance" and the elasticity of state power in wartime Japan. That is to say, national mobilization was less a seamless convergence of patriotic interests among state and nonstate actors and more of an awkward, clumsy dance between state and society with each entity taking turns leading the other, whirling, leaping, stumbling through war. Looking at the munitions worker - and other cultural tricksters of wartime Japan-is thus the first step in understanding how Japanese people gave meaning to the war at the time and not through the prism of defeat and occupation, which has so powerfully shaped the postwar histories of the Asia-Pacific War.

\section{Acknowledgments}

I wish to thank Gordon M. Berger, Brett Sheehan, Eric Rath, Clinton Godart, Sunyoung Park, Paul Lerner, Kyu Hyun Kim, Michiko Ito, the USC dissertation 
reading group at the Huntington Library, and the USC Visual Studies dissertation reading group. I am grateful for the excellent and constructive critiques from two anonymous JAS reviewers. My thanks to Mark Driscoll, who first suggested that I think about the "elasticity" of the Japanese state. The genesis of this article began at the University of Tokyo's Interfaculty Initiative of Information Studies under the kind sponsorship of Yoshimi Shun'ya. Research was supported by the Fulbright-IIE grant, the Social Science Research Council-International Dissertation Research Fellowship, and the University of Kansas New Faculty General Research Fund.

\section{List of References}

Akazawa Shirō, Kitagawa Kenzō, and Yui Masaomi, eds. 1985. "Shiryō 9: Shōwa 17-nendo keizai hanzai gaisetsu (1943.4)" [Document 9: Survey of economic crimes for 1942 (April 1943)]. In Shiryō Nihon gendaishi 13: Taiheiyō sensōka no kokumin seikatsu [Historical materials contemporary history of Japan 13: National people's daily life during the Pacific War], 106-19. Tokyo: Ōtsuki shoten.

Ambaras, David. 2006. Bad Youth: Juvenile Delinquency and the Politics of Everyday Life in Modern Japan. Berkeley: University of California Press.

Aramata Hiroshi. 1996. Kessenka no yūtopia [Utopia under decisive war]. Tokyo: Bungei shunjū.

Awaya Kentarō. 1977. "Kokumin dōin to teikō" [National people mobilization and resistance]. In Nihon rekishi 21: Kindai 8 [Japanese history 21: Modern 8], eds. Imai Seiichi et al., 161-211. Tokyo: Iwanami shoten.

Bassil-Morozow, Helena. 2015. The Trickster and the System: Identity and Agency in Contemporary Society. New York: Routledge.

DAi Nippon shokUgyō SHIDō KYōKAI, ed. 1939. Shokugyō shidō panfuretto dai-16-shū: Jikyokuka ni okeru rōmu jukyū to shokugyō shidō [Employment guidance pamphlet number 16: Labor supply and demand and employment guidance in the crisis]. Tokyo: Dai Nippon shokugyō shidō kyōkai.

Francks, Penelope. 2009. The Japanese Consumer: An Alternative Economic History of Modern Japan. Cambridge: Cambridge University Press.

Furukawa Takahisa. 2003. Senjika no Nihon eiga: Hitobito wa kokusaku eiga wo mita ka [Japanese film in wartime: Did people watch national policy films?]. Tokyo: Yoshikawa kōbunkan.

Garon, Sheldon. 1997. Molding Japanese Minds: The State in Everyday Life. Princeton, N.J.: Princeton University Press.

. 2000. "Luxury Is the Enemy: Mobilizing Savings and Popularizing Thrift in Wartime Japan." Journal of Japanese Studies 26(1):41-78.

Gordon, ANDrew. 1985. The Evolution of Labor Relations in Japan: Heavy Industry, 1853-1955. Cambridge, Mass.: Harvard University Press.

Hagiwara Sakutarō. 1941. "Fūzoku jihyō" [Commentary on social customs]. Nihon no fūzoku (June):84-88.

Наsнiмото Еıкісні. [1937] 1975. "Shinkō kōgyō chitai wo yuku" [Going to the emerging industrial sector]. Bungei shunjū (November). Reprinted in Dokyumento Shōwa sesōshi: Senchū hen [Documents of Shōwa social history: Wartime edition], ed. Heibonsha henshūbu, 81-86. Tokyo: Heibonsha.

Havens, Thomas R. H. 1978. Valley of Darkness: The Japanese People and World War Two. New York: W.W. Norton. 
Hayashi Tatsuo. 1940. "Fūzoku no konran" [Confusion of social customs]. Tosho (August):20-25.

Hımuro, Yoshio. 1941. Tatsu shōnenkō [Arise factory youths]. Tokyo: Kasumigaseki shobō.

Hyde, Lewis. 1998. Trickster Makes This World: Mischief, Myth, and Art. New York: Farrar, Straus, and Giroux.

Hynes, William J., and William G. Doty, eds. 1997. Mythical Trickster Figures: Contours, Contexts, and Criticisms. Tuscaloosa: University of Alabama Press.

Itō Koreyuki, ed. 1943. Shōnen sangyō senshi to naru made: Warera wa tatakawaneba naranu [Until we become industrial warriors: We must fight]. Nagoya: Nagoya chūgokumin shokugyō shidōsho.

Katō Etsurō, ed. 1944. Zōsan mangashū: Zen Nippon seinen mangaka kyōkai dai-ichi sakuhinsh $\bar{u}$ [Increased production manga collection: All-Japan Young Cartoonist Association first portfolio collection]. Tokyo: Shinkigensha.

Katō Yūjı. 1970. Nihon teikokushugika no rōdō seisaku [Labor policy under Japanese imperialism]. Tokyo: Ochanomizu shobō.

Kikuta Kazuo. 1941. "Fūzoku hihan no peiji: kore dake wa oyamenasai, Aa Riizento sutairu" [Social mores criticism page: Just stop this, ahh, the regent style]. Sutairu (March):46.

Kitagawa Kenzō. 1988. "Senjika no sesō fūzoku to bunka” [Social conditions, customs, and culture in wartime]. In Jügonen sensō shi 2: Nitchū sensō [History of the fifteenyear war 2: The Sino-Japanese War], eds. Fujiwara Akira and Imai Seiichi, 225-62. Tokyo: Aoki shoten.

Kitano Shigeo. 1944. Gunjūshō oyobi gunjū kaisha hō [The Munitions Ministry and the Munitions Company Law]. Tokyo: Takayama shoin.

Korwai Kiyoshi. 1939. "Sensō to shakai seikatsu" [War and social daily life]. Kaizō (May):94-103.

KYōchōKAI, ed. 1942. Rōdō nenkan Shōwa jūshichi-nen ban [Labor yearbook 1943]. Tokyo: Kyōchōkai.

— , ed. 1944. Senji rōdō jijō [Wartime labor situation]. Tokyo: Kyōchōkai.

MaEda Hideo. 1938. "Jihenka ni okeru shōnen hogo ni tsuite" [Youth protection under the incident]. Jido (November):50-57.

Mimura, Janis. 2011. Planning for Empire: Reform Bureaucrats and the Japanese Wartime State. Ithaca, N.Y.: Cornell University Press.

Nagasawa Kunio. 1939. "Sensō ga umu shōnen hanzai mondai" [The problem of youth crime born from the war]. Kaizō (December):262-69.

Naitō Hanae. 2007. "Dansei oshare no hirogari to kokumin fuku no seitei: Zasshi Sutairu wo tegakari ni” [The expansion of men's style and the establishment of the national uniform: A look at Sutairu magazine]. In Gendai Nihon wo kangaeru tame ni: Senzen Nihon shakai kara no shiza [Understanding contemporary Japan: Viewpoints from prewar Japanese society], eds. Suzaki Shin’ichi and Naitō Hanae, 132-53. Matsudo-shi: Azusa shuppansha.

Nishida Yoshiaki. 1994. "Senjika no kokumin seikatsu jōken-Senji yami keizai no seikaku wo megutte" [Daily life conditions in wartime-The nature of the wartime black market economy]. In Nihon teikokushugi shi 3: Dai niji taisen ki [History of Japanese imperialism 3: The Second World War era], ed. Ōishi Kachirō, 369-98. Tokyo: Tōkyō daigaku shuppankai.

Nishitani Yahei. 1942. Tatakau keizai [Fighting economy]. Tokyo: Shin kōasha. 
ŌHara SHAKai MONDAi Kenkyūjo, ed. 1964. Taiheiyō sensōka no rōdōsha jōtai [Worker conditions during the Pacific War]. Vol. 1. Tokyo: Tōyō keizai shinpōsha.

Оната AкIRA. 1940. "Shain to shokkō" [Company man and factory worker]. Kingu (February):342.

Onozawa Akane. 2006. "Gunju kōjō chitai ni okeru junketsu undō: Gunma-ken wo chūshin ni" [The purity league in military munitions factory region: A look at Gunma Prefecture]. In Senji Nihon no keizai saihensei [The economic reorganization of wartime Japan], eds. Hara Akira and Yamazaki Shirō, 311-40. Tokyo: Nihon keizai hyōronsha.

Rice, Richard. 1990. “Japanese Labor in World War II.” International Labor and Working-Class History 38:29-45.

SASAKI KeI. 2005. "Kenkyū nōto: Chōyō seidozō no saikentō—Sono saihen tōgō saku ni chūmoku shite" [Research note: Reexamining the image of the labor conscription system-Focusing on its restructuring and consolidation policies]. Jinmin no rekishigaku 165:26-41.

—. 2011. “Sangyō senshi’ no sekai-Sōryokusen taiseika no rōdōsha bunka” [The world of the "industrial warrior"-Worker's culture under the total war system]. Rekishi hyōron 737:52-66.

Sно̄ко̄sно̄ вUкКА күокU. 1940. "Shashihin no seizō hanbai kinshi”" [Ban on production and sale of luxury items]. Shūhō 195:12-13.

SHокUGYō KYōKAI, ed. 1942. Nihon shokugyō taikei, dai hachi [Japan employment outline, part eight]. Tokyo: Shokugyō kyōkai.

Silverberg, Miriam. 2006. Erotic Grotesque Nonsense: The Mass Culture of Japanese Modern Times. Berkeley: University of California Press.

SugiYama Heisuke. 1938. "Shakai jihyō" [Social commentary]. Gendai (August):85-89.

TAKaOKa Hiroyuki. 2001. "Dai Nippon sangyō hōkokukai to 'kinrō bunka'-Chūō honbu no katsudō wo chūshin ni" [The greater Japan patriotic industrial service and "labor culture": The activities of the central headquarters]. In Senjika no senden to bunka: Nenpō Nihon gendaishi dai-shichi-gō [Wartime propaganda and culture: Contemporary Japanese history annual report volume seven], ed. Akazawa Shirō, 37-80. Tokyo: Gendai shiryō shuppan.

Tansman, Alan. 2009. "Introduction: The Culture of Japanese Fascism." In The Culture of Japanese Fascism, ed. Alan Tansman, 1-28. Durham, N.C.: Duke University Press.

Tasaki Nobuyoshi and Arakawa Shōjı. 1988. "Sōdōin taisei to minshū-Toshi to nōson" [Mobilization system and the people-City and village]. In Jügonen sensō 2: Nitch $\bar{u}$ sensō [Fifteen-year war 2: The Sino-Japanese War], eds. Fujiwara Akira and Imai Seiichi, 183-224. Tokyo: Aoki shoten.

TōKYō Asahi Shinbun. 1938a. August 27.

- 1938b. October 5.

- 1939a. August 15.

—. 1939b. September 20.

—. 1940a. April 9.

- 1940b. June 8.

- 1943. January 5.

1944. October 6.

TŌKYō KOMAMONO KESHŌHIN SHŌHŌSHA, ed. 1943. Komamono keshōhin nenkan Shōwa jūhachi nen [Haberdasheries cosmetics yearbook Shōwa 18]. Tokyo: Tōkyō komamono keshōhin shōhōsha. 


\section{4}

Benjamin Uchiyama

WaKakuwa Midori. 2006. "Sōryokusen taiseika no shiseikatsu tōsei: Fujin zasshi ni miru 'senji ifuku' kiji no imi suru mono" [Controls over private life under the total war system: The meaning of "wartime attire” articles as seen in women's magazines]. In Gunkoku no onnatachi: Sensō, bōryoku to josei 2 [Women of the military country: War, violence, and women 2], ed. Hayakawa Noriyo, 194-220. Tokyo: Kōbunkan.

Wilk, Richard. 2006. "Consumer Culture and Extractive Industry on the Margins of the World System.” In Consuming Cultures, Global Perspectives: Historical Trajectories, Transnational Exchanges, eds. John Brewer and Frank Trentmann, 123-43. Oxford: Berg Publishers.

Yamanouchi, Yasushi. 1998. “Total War and System Integration: A Methodological Introduction.” In Total War and 'Modernization', eds. Yamanouchi Yasushi, J. Victor Koschmann, and Narita Ryūichi, 1-39. Cornell East Asia Series no. 100. Ithaca, N.Y.: Cornell University East Asia Program.

YAMAZAKi Shirō. 2011. Senji keizai sōdōin taisei no kenkyū [Studies of the wartime economic mobilization system]. Tokyo: Nihon keizai hyōronsha.

Yomiuri Shinbun. 1937. December 19.

- 1938. May 23.

- 1939. June 2.

—. 1940a. January 5.

—. 1940b. April 13.

-. 1940c. April 17.

—. 1940d. April 23.

—. 1940e. May 10.

—. 1940f. July 13.

—. 1941. December 5.

—. 1942a. May 31.

- 1942b. September 6.

—. 1942c. September 12.

- 1942d. October 9.

—. 1943a. March 14.

—. 1943b. May 10.

—. 1943c. May 28.

—. 1943d. July 7 .

—. 1944. February 8.

Yoshimura SAWAO. [1942] 1975. "Shōnen-kō to sakariba" [Factory boys and amusement districts]. Chūō kōron (October). Reprinted in Dokyumento Shōwa sesōshi: Senchū hen [Documents of Shōwa social history: Wartime edition], ed. Heibonsha henshūbu, 86-90. Tokyo: Heibonsha. 